Journal of Balkumari College

ISSN : 2467-9321 Website: http://www.nepjol.info/index.php/jbkc

Volume : 9, Issue : 1, June 2020, Page No.: 95-100

\title{
Awareness Level of College Students on Consumer Protection Practices in Chitwan
}

\author{
Ashmita Dahal Chhetri* \\ M.Phil. Scholar in Management \\ Kathmandu University, Nepal
}

\begin{abstract}
Any individual who purchases products or services for his personal use is called a consumer. A consumer is one who is the decision maker whether to buy or not to buy an item. And It is true that the consumer is the king of the market, but in reality consumers are treated very badly in the market. The consumers are cheated in different ways by middlemen like adulteration, under-weight of goods, selling goods of inferior quality and duplicated goods, charging higher prices, misleading advertisement in the media, etc. The consumers are not sure of getting qualitative goods as per their demand and price payments. The most important step in consumer education is making them aware about consumer rights and to empower them for selfprotection from the different unethical behaviors of the market. Consumer education is an important part of this process. Consumer education at the college level is an important process to enhance the capacity of the youth particularly the students to take the responsibility for their own life, their family, obligations to society and the environment. Consumer education helps the students to participate in the social life, as competent citizens. Students are not only learning about the consumer rights and duties but also teach their parents and the community, thereby they are enriching the society. This research is based on analytical and descriptive research. The method of data collection is based on primary method. The researcher personally involved in the data collection process with the help of structured questionnaire. The method of sampling technique adopted is Convenience sampling. In general, the level of awareness of college students on consumerism is satisfactory. It is found that the practices and behavior during buying process is appreciable.
\end{abstract}

Key Words: consumers, consumer education, awareness, consumer protection, consumer rights

\section{INTRODUCTION}

A consumer is a person or a group who intends to order, orders, or uses purchased goods, products, or services primarily for personal, social, family, household and similar needs, not directly related to entrepreneurial or business activities. A consumer is one who is the decision maker whether to buy or not to buy an item. Consumers form the largest economic group in any country. It is often said that the consumer is king, but in reality consumers are treated very badly in the market. In this age of capitalism and globalization, the main objective of each producer is to maximize his profit. In each and every possible way the producer are trying to increase the sale of their products. Therefore, in fulfillment of their aim they forgot the interests of consumer s and start exploiting them for example - overcharging, under weighing, selling of adulterated and poor quality goods, misleading the consumers by giving false advertisement etc. Thus, in order to save him from being cheated, it is necessary for a consumer to be aware. In this way, consumer awareness means noticing the general public about consumer rights and protective legislations. Consumer and consumer awareness are interrelated to each other. Education is a lifelong process of constantly acquiring relevant information, knowledge and skills. Consumer education is an important part of this process. Consumer education at the college level is an important process to enhance the capacity of the youth particularly the students to take the responsibility for their own life, their family, obligations to the society and the environment.

Consumers are the largest economic group in any country. They are the central point of all economic activities. The ultimate aim of production, storage and distribution is to ensure consumption of goods and services to the satisfaction of the consumers. Consumer awareness means being conscious of having knowledge about the various consumer production laws, redress mechanism and the consumer rights which include right to protection

*CCorresponding author: 19606_ashmita@kusom.edu.np 
of health and safety from goods and services that the consumer buy, right to be informed about the quality, price, potency, purity and standard of good, right to choose the best from a variety of others, right to get representation if there is any grievance or suggestion, and right to seek redress against unfair trade practice or unscrupulous exploitation.

\section{REVIEW OF LITERATURE}

The review of literature reveals few studies on consumer protection practices. The knowledge gained from the studies with a view to derive guidelines for the present study. An attempt is made for the investigation and the scope of the review is restricted to the variables selected for the present study.

Jayasubramanian and Vaideke, M.A. (2012) studied consumer awareness and Attitude towards consumer protection measures. Their study revealed that no significant association between gender and attending awareness meetings. They also studied the association between age and attending awareness meetings. Study also found the association between age and attending awareness conferences. Sundaram and Balaramalingam (2012), Women awareness on consumer rights-A Study with reference to Vellore city. The result showed that women consumers showed low level of awareness about consumer rights. The main reason for low awareness of consumer rights among women consumers is low education and low socio-economic status.

Deepika, J. and Ratan Kumarai, D. (2014) studied on title of Awareness on Legal act of Consumer Protection among Students. The study was conducted to find the awareness level among the students towards various consumer protection legislations. Majority respondents are aware of the Indian Penal Code, 1860. Majority respondents are aware of various acts. Low level of awareness was reported towards the Hire Purchase Act and the Railway Claims and Tribunal Act. In the study, it was found that majority students getting awareness through newspapers, journals. The awareness towards Consumer Protection Act is 53.3\%. Sewanand (2014), have depicted in their study Consumer Awareness and Consumer Protection Act-A study. This study reveals that all the respondents are having general awareness in relation to consumer protection. They are well- versed with the term JAGO GRAHAK JAGO almost in all respect. Quality parameters/standards similar to ISO, ISI Agmark, etc., are also not new to them. Chandra, A.K. (2014), studied the working of Consumer Discussion of Raipur locale and he additionally breaks down the consumer development and featured the issues being looked by the Consumer Gathering of Raipur region. He analyzed the hypothesis with respect to consumer learning and awareness.

Mohan,S and Suganthi,V. (2015) have studied in their research work entitled the Rural Consumers Awareness about Consumers Rights. The study conducted to know the awareness level of rural consumers about the consumer's rights. The study revealed that there is significant association between age, educational qualification, marital status and monthly income of rural consumers and their awareness about consumer rights. And there in significant association between gender, type of family, occupation and monthly income of rural consumers and their level of consumer rights awareness.

Horen Goowalla (2016), studied under A study on consumer protection: Its awareness among the rural people in Assam: A case study with special reference to Jorhat district of Assam. A survey was conducted on 400 consumers. $90 \%$ of the people surveyed have felt exploited by the seller at one time or the others. $75 \%$ people were aware of the Consumer Protection Act, $25 \%$ of the people are not. It is also found that $40 \%$ of graduate respondents were aware of the products and their quality while $30 \%$ Post Graduates.

Jamuna (2017), searched under the title, Consumer awareness and attitudes towards Consumer Protection Act1986. The study was conducted to find the consumer awareness level. In the study, responses were taken from the respondents related with consumer responsibilities. Majority respondents had given first rank to get guarantee and warranty card. It was also found that $67.14 \%$ respondents have awareness about the consumer forums and53.21\% respondents felt that formalities are simple. Majority respondents disagreed with the argument that Consumer awareness increased with Consumer Protection Act. 25\% respondents felt that trade has increased due to Consumer Protection Act. Only 20\% respondents had given the opinion that Consumer Protection Act created quality consciousness among the consumer. 


\section{SIGNIFICANCE OF THE STUDY}

It has been observed very often that consumers are not worried about the different unethical actions seen in the market. Even among the educated, the rate of ignorance on consumer rights especially the younger generation is high. Until and unless the consumers become aware different laws and about their rights, the different unethical behaviors such as overcharging, under weighing, selling of adulterated and poor quality goods, misleading the consumers by giving false advertisement etc. are not controlled and this has been the important research area for creating consumer awareness. But there has been less study and experiment in this subject and within this area, the research done with targeting college students is rare.

So, in this research we have selected college students as respondents for this study because through which we can reach more people. Many exploitation and unfair trade practices happened due to our ignorance on consumer rights. So, this study will help to educate about the consumer awareness in the college students.

\section{OBJECTIVES OF THE STUDY}

The main objective of the study is to study the level of awareness of college students on consumer rights and the specific objectives are as follows:

- To analyze awareness level of consumer protection.

- To analyze existing practice while purchasing goods and availing services.

\section{RESEARCH METHODS}

This research is based on analytical and descriptive research. The method of data collection is based on primary method. The researcher personally involved in the data collection process with the help of structured questionnaire. The method of sampling technique adopted is Convenience sampling. Researcher has collected data from 4 different colleges located in Chitwan. The sample size is 60.The number of respondents from each institution is fifteen. Simple percentage method and two way table was used to analyze the collected data.

\section{DATA ANALYSIS AND INTERPRETATION}

Table 1: Gender wise Classification of students

\begin{tabular}{|l|c|c|}
\hline Gender & Number & Percentage \\
\hline Male & 28 & 46.6 \\
\hline Female & 32 & 53.33 \\
\hline Total & $\mathbf{6 0}$ & $\mathbf{1 0 0}$ \\
\hline
\end{tabular}

This table is prepared to classify the total respondents i.e., college students in to gender wise. Out of sixty students 28 are male and 32 are female. Hence, more or less equal number of students is taken from both genders.

Table 2: Graduation wise Classification of students

\begin{tabular}{|l|c|c|}
\hline Graduation & Number & Percentage \\
\hline Under Graduates & 24 & 40 \\
\hline Post Graduates & 36 & 60 \\
\hline Total & $\mathbf{6 0}$ & $\mathbf{1 0 0}$ \\
\hline
\end{tabular}

From the above table it is clear that out of sixty total students 24 are studying under graduates and 36 are studying post-graduation degrees. Most of the students are doing post-graduation studies. Hence we can say most of our respondents are matured enough to talk as well as give opinion on consumerism.

Table 3: Practice of asking Price of the product during Buying

\begin{tabular}{|l|c|c|}
\hline Enquiring Price While Buying & Number & Percentage \\
\hline Yes & 55 & 91.67 \\
\hline No & 5 & 8.33 \\
\hline Total & $\mathbf{6 0}$ & $\mathbf{1 0 0}$ \\
\hline
\end{tabular}


It is good to note that $91.67 \%$ of the students had a practice of enquiring price of the products before they own them. It is really a surprise fact. Nowadays many youngsters hesitated to ask price before they buy. Some of them never know the price of the products even the purchase process gets over. It shows their urgency and carelessness in this regard. We need not blame the students community here, because many family man are also followed the same practice while buying.

Table 4: Practice of Checking MRP, Date of Expiry, etc.

\begin{tabular}{|l|c|c|}
\hline Checking MRP, Date of Expiry & Number & Percentage \\
\hline Yes & 60 & 100 \\
\hline No & 00 & 00 \\
\hline Total & $\mathbf{6 0}$ & $\mathbf{1 0 0}$ \\
\hline
\end{tabular}

Again it is a surprised to note that, $100 \%$ of the students, irrespective of their gender had checked the details of MRP, Date of manufacturing and Date of Expiry on the pack before they are buying. This is an appreciable practice of the students. This is the first step to express our alertness towards self-protection from unscrupulous businessmen and traders. This practice shows their better level of awareness on consumerism.

Table 5: Observing instruments used for Measurement

\begin{tabular}{|l|c|c|}
\hline Observing Instruments of Measurement & Number & Percentage \\
\hline Yes & 52 & 86.67 \\
\hline No & 08 & 13.33 \\
\hline Total & $\mathbf{6 0}$ & $\mathbf{1 0 0}$ \\
\hline
\end{tabular}

It is happy to note that $86.67 \%$ of the student respondents listening the instruments and balances which were used while measuring and weighing the products at the time buying. This kind of practice will helps to identify fraudulent businessmen and poor traders. A fair and genuine market environment is possible only when we start following this kind of practices while buying the products.

Table 6: Knowledge on Consumer Court

\begin{tabular}{|l|c|c|}
\hline Heard about Consumer Court & Number & Percentage \\
\hline Yes & 45 & 75 \\
\hline No & 15 & 25 \\
\hline Total & $\mathbf{6 0}$ & $\mathbf{1 0 0}$ \\
\hline
\end{tabular}

Out of sixty respondents $75 \%$ are heard about the existence of consumer court, remaining students do not know the consumer court. Even though the awareness level on consumer court is satisfactory, but still one fourth of the students need to know about consumer courts.

Table 7: Attended programs on Consumerism

\begin{tabular}{|l|c|c|}
\hline Heard about Consumer Court & Number & Percentage \\
\hline Yes & 46 & 76.6 \\
\hline No & 14 & 23.33 \\
\hline Total & $\mathbf{6 0}$ & $\mathbf{1 0 0}$ \\
\hline
\end{tabular}

Out of sixty respondents only $76.6 \%$ including (Post Graduation students) are attended programs on Consumerism. Remaining $23.33 \%$ were not attended any programs on consumerism. Hence the colleges have a major role to educate their students on consumerism. 
Table 8: Two Way Analysis (gender wise comparison of responses)

\begin{tabular}{|l|c|c|c|c|c|c|c|c|}
\hline & \multicolumn{4}{|c|}{ Male 28 } & \multicolumn{4}{c|}{ Female 32 } \\
\hline Responses on Consumerism (various aspects) & Yes & $\mathbf{\%}$ & $\mathbf{N o}$ & $\mathbf{\%}$ & Yes & \% & No & $\%$ \\
\hline Knowledge on Consumer Rights & 20 & 71.42 & 8 & 28.57 & 20 & 62.5 & 12 & 37.5 \\
\hline Bitter Experience in advertisements & 22 & 78.57 & 6 & 21.43 & 26 & 81.25 & 6 & 18.75 \\
\hline Satisfaction on Functioning of Local Ration Shops & 15 & 53.57 & 13 & 46.43 & 15 & 46.87 & 17 & 53.12 \\
\hline Helping others towards self-protection & 13 & 46.43 & 15 & 53.57 & 10 & 31.25 & 22 & 68.75 \\
\hline Able to answer questions on Consumer Courts & 20 & 71.43 & 8 & 28.5 & 25 & 78.12 & 7 & 21.87 \\
\hline Attending Consumer Education programs at College & 10 & 35.71 & 18 & 64.28 & 12 & 37.5 & 20 & 62.5 \\
\hline
\end{tabular}

This table helps to compare the level of awareness of college students on gender basis. It is also helpful to know their practice towards self-protective practice and helping others towards better protection from false advertisements.

\section{Some Highlights of the above table}

28.57 percentage of male and $37.5 \%$ of female do not have knowledge on consumer rights. In case of bitter experience on advertisement is concerned; female students $(81.25 \%)$ are very disappointed than male gender (78.57\%). $46.43 \%$ of male students and $53.12 \%$ of female students are not satisfied on functioning of local ration shops. It is happy to say that the awareness level on consumer court is satisfied in both genders. More than half of the male students and two third of the female students are not attending programs on consumer education.

Table 9: Two Way Analysis (Graduation wise comparison)

\begin{tabular}{|l|c|c|c|c|c|c|c|c|}
\hline Responses on Consumerism (various aspects) & \multicolumn{3}{|c|}{ Under Graduates (24) } & \multicolumn{3}{c|}{ Post Graduates (36) } \\
\hline & Yes & $\mathbf{\%}$ & No & $\mathbf{\%}$ & Yes & \% & No & \% \\
\hline Knowledge on Consumer Rights & 18 & 75 & 6 & 25 & 20 & 55.56 & 16 & 44.44 \\
\hline Bitter Experience in advertisements & 18 & 75 & 6 & 25 & 22 & 61.11 & 14 & 38.88 \\
\hline Satisfaction on Functioning of Local Ration Shops & 15 & 62.5 & 9 & 37.5 & 19 & 52.78 & 17 & 47.22 \\
\hline Helping others towards self-protection & 15 & 62.5 & 9 & 37.5 & 10 & 27.78 & 26 & 72.22 \\
\hline Able to answer questions on Consumer Courts & 20 & 83.33 & 4 & 16.67 & 15 & 41.67 & 21 & 58.33 \\
\hline Attending Consumer Education programs & 17 & 70.83 & 7 & 29.16 & 12 & 33.33 & 24 & 66.67 \\
\hline
\end{tabular}

This table is prepared to compare the opinion of students on the same points but on the basis of their graduation level. This analysis will helpful to know, how extent the PG students are shown their matured behaviour while comparing the under graduate students.

\section{Some highlights of the above table}

Even though we have more respondents in Post-Graduation category, the level of awareness of UG students is better in many aspects. Especially the basic knowledge on consumer rights and consumer courts, attending programs on consumerism and helping others towards self-protection the UG students are comparatively better than PG students. PG students concentrate more on regular studies. In case of functioning the local ration shops, in both category equal responses were recorded.

\section{LIMITATIONS OF THE STUDY}

1. Basically, this study is based on primary data.

2. The study area of this research is limited to Chitwan district.

3. This study is based upon the responses given by 60 college students belonging 4 different colleges in Chitwan. Hence it may not applicable to other areas.

4. The sample size of the project is 60 only. 


\section{CONCLUSION AND FINDINGS}

In general, the level of awareness of college students on consumerism is satisfactory. It is found that the practices and behavior during buying process is appreciable. They have checked the tools and instruments used in the measurement while buying. They have verified MRP, Date of Mfg. and Date of Expiry details too. The awareness level of the UG students is better than the PG students in many aspects. PG students are not much involved in educating others. Not much difference found between the students of two genders with regard to the level of awareness on consumer education. The study found that the female gender hesitated to involve in programs of conducted outside the campus especially in attending programmes and enriching the community as well.

\section{MANAGERIAL IMPLICATIONS AND SUGGESTIONS}

1. Even though sizeable respondents had met bitter experience in false advertisement but they never worry and do not proceed to fight against unfair practices. Hence it is suggested to raise questions bravely. They must know their rights. Students may involve in helping others to protect from false advertisement and give consumer education.

2. Number of arguments between the traders and consumers and no struggle found against exploitation in the society. It shows poor association of them. Hence it is suggested to form some associations to empower consumer forum at local level.

3. It is found that the programs conducted by colleges on consumer education not adequate. Hence the authorities of education can plan to conduct such a events once a year. They have to extend this awareness Programme in the nearby local places also for the benefit of community.

\section{REFERENCES}

Chandra,A.K. Consumer Perception and Awareness about Consumer Rights and Consumer Protection Act: A study in Raipur district, published in The International Journal for Research in Social Science \& Management, Dec2014,"Volume 1, p 59-69.

Deepika,J. and RatanKumarai,D. (2014), "A study on awareness on legal act of consumer protection among students", International Journal of Science And Research, volume3(issue11),www.ijsr.net.

Horen Goowalla, "A study on consumer protection: Its awareness among the rural people in Assam: A case study with special reference to Jorhat district of Assam", International Journal of research and development in technology and management sciences, 2015 Vol.20 Issue 6.

Jamuna, S. (2017), Consumer awareness and attitudes towards consumer protection act 1986-A study with reference to consumer in Virudhinagardistrict,Indian Journal of Applied research, volume 4, issue April 2014, page no 7-10.

Jayasubramanian, P. and Vaideke, M.A. (2012), "A Study On Consumer Awareness And Attitude Towards Consumer Protection Measures". Indian journal of applied research, volume: 1(issue:12).

Mohan, S. and Suganthi, V. (2015), "Rural Consumers" Awareness about Consumer Rights", International Journal of Innovative Research \&Development,vol2(Issue 11),page no 136-141.

Sewanand, "Consumer Awareness And Consumer Protection Act-A Study", International Journal of Transformations in Business Management, 2014, Vol.No1, issue No 6.

Sundaram, N. and Balaramalingam, C. (2012):"Women Awareness on Consumer Rights-A Study with reference to Vellore city". International Journal of Research in Commerce, Economics And Management, volume No 2(issue No12).

http://iosrjournals.org/iosr-jbm/papers/Vol19-issue7

https://rccp.gov.in/consumerprotection-india.php 